\title{
Research Note \\ Diet composition of franciscana dolphin Pontoporia blainvillei from southern Buenos Aires, Argentina and its interaction with fisheries
}

\author{
Composición de la dieta del delfín franciscana Pontoporia blainvillei en el sur de \\ la provincia de Buenos Aires, Argentina y su interacción con las pesquerías

\section{María Natalia Paso-Viola ${ }^{1,3}$, Pablo Denuncio ${ }^{2}$, María Fernanda Negri ${ }^{3}$, Diego Rodríguez ${ }^{2}$, Ricardo Bastida ${ }^{2}$ and Humberto Luis Cappozzo ${ }^{1,4}$}

\begin{abstract}
${ }^{1}$ Laboratorio de Ecología, Comportamiento y Mamíferos Marinos, Museo Argentino de Ciencias Naturales 'Bernardino Rivadavia' (MACN-CONICET), Av. Ángel Gallardo 470, Ciudad Autónoma de Buenos Aires C1405DJR, Argentina. npasoviola@gmail.com

${ }^{2}$ Instituto de Investigaciones Marinas y Costeras (IIMyC-CONICET), Departamento de Ciencias Marinas, Facultad de Ciencias Exactas y Naturales, Universidad Nacional de Mar del Plata, Funes 3350, Mar del Plata B7602AYL, Argentina ${ }^{3}$ Laboratorio de Ecología y Conservación de Vida Silvestre, Centro Austral de Investigaciones Científicas (CONICET). Houssay 200), Ushuaia V9410BFD, Tierra del Fuego, Argentina

${ }^{4}$ Fundación Azara - Universidad Maimónides, Hidalgo 775, 7mo piso, Ciudad de Buenos Aires, Argentina
\end{abstract}

\begin{abstract}
The present study provides information about the diet composition of franciscana dolphin, Pontoporia blainvillei, from southern Buenos Aires coast, Argentina. From 2003 to 2011 we collected 66 franciscana dolphins that were incidentally entangled in artisanal fishing nets. We analyzed the stomach contents and estimated the prey size in order to evaluate the diet composition and the overlapping with fisheries. We identified 11 prey species in the stomach contents; only two of them were important in the diet, the striped weakfish, Cynoscion guatucupa, and the squid, Loligo sanpaulensis. Almost all the prey found in the diet of franciscana dolphins are of commercial interest. The overlapping of target species and prey that are subject to overfishing could enhance the vulnerability of franciscana by reducing food availability.
\end{abstract}

Key words: Prey species, Pontoporia blainvillei, southern Buenos Aires, fisheries

\section{INTRODUCTION}

Commercial fisheries have fundamentally altered marine ecosystems transforming the structure and functioning of many marine food webs (Pauly et al. 1998, 2002) and depleting stocks of some species to near extinction (Casey \& Myers 1998). Fisheries operate at all levels of marine food webs, including the lower trophic levels, potentially providing evidence of bottom-up and top-down effects (Pauly \& Palomares 2005). One reason given for the move toward ecosystem-based management is concern that fisheries are overfishing fish species that are prey for many marine predators, especially marine mammals (Jensen et al. 2012). Thus, competition between marine mammals and fisheries for marine resources, whether real or perceived, has become a major issue for several countries (Morissette et al. 2012). Interactions between marine mammals and fisheries can be classified as direct or operational and indirect or ecological. In operational interactions, marine mammals come into physical contact with fishing gear (Northridge 1984). These interactions can result in the bycatch of marine mammals, recognized as the primary threat to several endangered species of marine mammals (Reeves et al. 2003). In ecological interaction, marine mammals and fisheries interact indirectly through trophic pathways, competing for food resources (Beverton 1985).

The franciscana, Pontoporia blainvillei (Gervais \& d'Orbigny 1844), is an endemic dolphin of the Southwestern Atlantic Ocean, which dies incidentally in coastal fishing nets all along its geographical distribution (Corcuera 1994, Secchi et al. 1997, Bordino \& Albareda 2004), from Itaúnas ( $18^{\circ} 25^{\prime} \mathrm{S}, 30^{\circ} 42^{\prime} \mathrm{W}$, Brazil) (Siciliano 1994 ) to Península Valdés ( $42^{\circ} 35^{\prime} \mathrm{S}, 64^{\circ} 48^{\prime} \mathrm{W}$, Argentina) (Crespo et al. 1998). This species is considered the most endangered small cetacean of the Southwestern Atlantic Ocean (Secchi et al. 2003), seriously and immediately affected by human activities (Secchi, 2010). Consequently, franciscana dolphin is classified as Vulnerable (A3d) by 
the International Union for Conservation of Nature (IUCN, Reeves et al. 2008). Even though the International Whaling Commission establishes an upper limit of $2 \%$ of the mortality rate for the species to be sustainable (Donovan \& Bjørge 1995), in Buenos Aires coast, were this study was carried out, mortality was estimated to be 2.5-3.7\% of the total population of Argentina (Cappozzo et al. 2007, Negri et al. 2012).

Several studies on trophic ecology of franciscana have been performed in Brazil (Ott 1995, Di Beneditto \& Ramos 2001, Bassoi 2005, Di Beneditto et al. 2009, Cremer et al. 2012), Uruguay (Fitch \& Brownell 1971, Praderi 1989) and Argentina (Rodríguez et al. 2002). However, the diet of this dolphin from southern Buenos Aires has not currently been reported. Feeding habits studies suggest that franciscana dolphin has a generalist and opportunistic feeding behavior, being fish, cephalopods and crustaceans the most common prey feed by this dolphin (Ott 1995, Rodríguez et al. 2002, Di Beneditto et al. 2009). The diet composition of franciscanas in northern Buenos Aires province includes prey of commercial interest that are subject to overfishing, establishing a principle of potential competition for resources (Rodríguez et al. 2002).

Dietary studies are important in understanding the ecological role of marine mammals and in formulating appropriate management plans in terms of their interactions with fisheries. Therefore, determining franciscana's preferred prey is crucial for assessing the potential competition with coastal fisheries and, most importantly, to understand its role in the ecosystem functioning (Secchi 2010). In this context, the objectives of this study were to determine the diet composition of franciscana dolphin in southern Buenos Aires coast, and to explore the potential overlap between dolphins' prey species and commercial species that are subject to overfishing.

\section{MATERIALS AND METHODS}

From 2003 to 2011 we collected 66 franciscana dolphins (25 females and 34 males) that were incidentally entangled in artisanal fishing nets of the southern coast of Buenos Aires province in Argentina ( $38^{\circ} 37^{\prime} \mathrm{S}, 58^{\circ} 50^{\prime} \mathrm{W}$ ). The study area includes four localities: Necochea $(\mathrm{N})$, Claromecó (CLA), Monte Hermoso (MH) and Bahía Blanca (BB) (Fig. 1). We worked in collaboration with the artisanal fishermen who were asked not to discard the incidentally captured dolphins. Fishermen collected franciscana

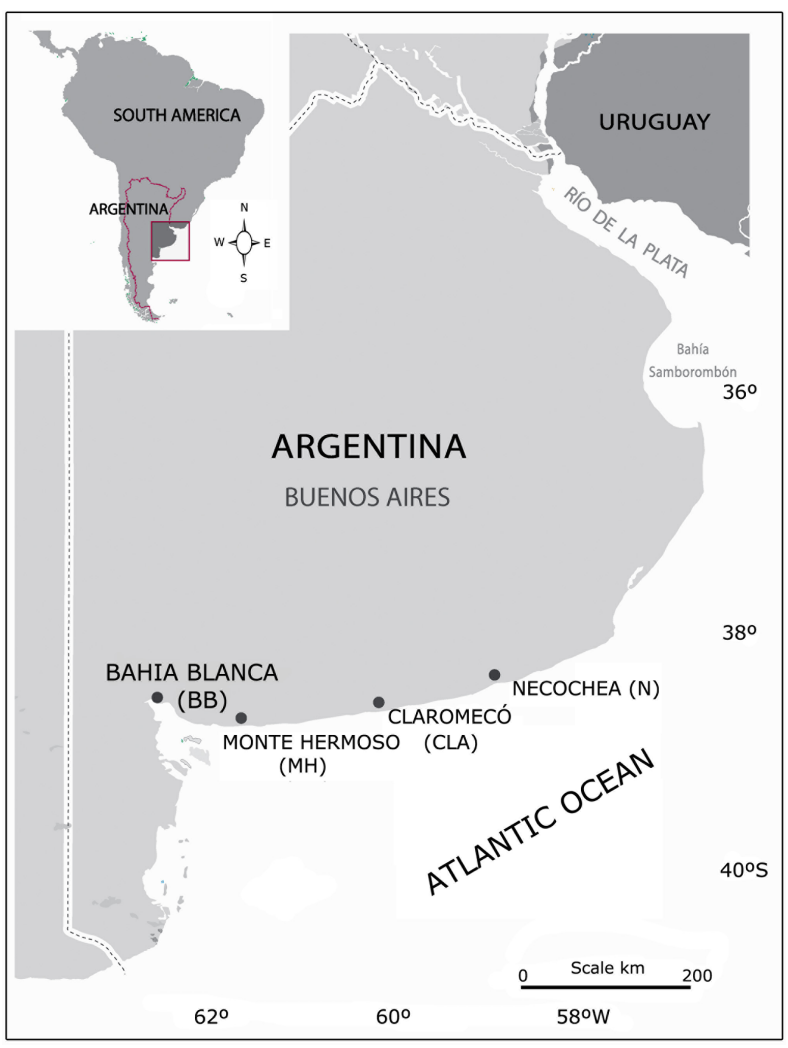

Figure 1. Study area in southern Buenos Aires province, Argentina. Necochea (N), Claromecó (CLA), Monte Hermoso (MH) and Bahía Blanca (BB) / Área de estudio al sur de la provincia de Buenos Aires, Argentina. Necochea (N), Claromecó (CLA), Monte Hermoso (MH) and Bahía Blanca (BB)

bycatch from gillnets and shrimpers that were set up to $50 \mathrm{~m}$ deep and $30 \mathrm{~km}$ from the coast (Negri et al. 2012). The animals were kept in freezers at $-20^{\circ} \mathrm{C}$ until necropsy was performed. Total length (TL) and weight of each specimen were recorded (Norris 1961).

Diet composition was analyzed through the study of hard remains in the stomach contents, which were recovered using sieves of different mesh sizes $(0.3$ and $0.5 \mathrm{~mm}$ ) and preserved in $70 \%$ ethanol. Prey items were identified to species level under stereoscopic microscope (25-40x) with laboratory catalogs and references (Pineda et al. 1996, Volpedo \& Echeverría 2000). The relative importance of prey species was evaluated using the index of relative importance (IRI) calculated as IRI $=[\% \mathrm{~N}+\% \mathrm{~W}]$ * \% FO and then transformed as percentage (\%IRI) (Pinkas et al. 1971). The frequency of occurrence (\%FO) was calculated as the number of stomachs in which a prey occurred, the numerical abundance $(\% \mathrm{~N})$ as the 
number of individuals of each prey type / total number of individuals of all prey types, and the reconstructed biomass $(\% \mathrm{~W})$ as the biomass of each prey type / total biomass represented by all prey; all these indexes were expressed as percentage (Castley et al. 1991, Cortés 1997). Differential rates of digestion among species may bias stomach content analyses in favor of species with large and robust hard parts (Bowen 2000). Thus, diet indexes were calculated considering teleosts, cephalopods and crustaceans separately.

The total length and the prey biomass were estimated through otoliths of fish and cephalopod beaks applying the formula proposed by Pineda et al. (1996), Rodríguez et al. (2002) and Bassoi (2005). Only intact otoliths, with little erosion in both sulcus and margins, were considered for this analysis. Crustaceans were measured when whole specimen was found; otherwise total length was estimated from existing regressions (De la Garza 2003).

For statistical analyses we selected the main prey species found in diet composition as those with \%FO > 70 and \%IRI $>80$. Differences in mean size of main prey between sex and among the four localities (N, CLA, MH, $\mathrm{BB})$ were analyzed with the non-parametric tests, MannWhitney, Kruskall-Wallis and Multiple Comparisons, because the data were not normally distributed. Spearman's rank correlation coefficients were calculated to measure the strength of the association between predators' length and estimated length of prey. All statistical analyses were performed using the software Statistica 7.0 (Statsoft, Inc.) and InfoStat.Ink (Di Rienzo et al. 2011). It was considered as statistical significance level $P \leq 0.05$.

\section{RESULTS AND DISCUSSION}

The mean $( \pm \mathrm{SD})$ TL of the franciscana dolphins was $118.4 \pm 19.2 \mathrm{~cm}$ (Range: 63-160.5 cm) (Table 1). Six individuals had only milk ( $\mathrm{TL}=78.7$ to $87.7 \mathrm{~cm}$ ) in their stomachs, one dolphin had an empty stomach and the others 59 presented solid remains. The smallest dolphin with solid food in their stomach was a male of $87.4 \mathrm{~cm}$.

The diet of franciscana dolphins all along it distribution range is composed by, at least, 76 food items (Danilewicz et al. 2002). In Brazil, a total of 25 prey species were found in franciscanas from north of Rio de Janeiro (Di Beneditto \& Ramos 2001) and 36 prey species in Rio Grande do Sul (Bassoi 2005). Finally, a total of 24 prey species were reported in the northern coast of Buenos Aires in Argentina by Rodríguez et al. (2002). The number of prey
Table 1. Franciscana dolphins analyzed in southern Buenos Aires, Argentina. $\mathbf{M}=$ male, $\mathrm{F}=$ female, $\mathrm{n}=$ number of stomach contents/ Delfines franciscana analizados en el sur de la provincia de Buenos Aires, Argentina. $\mathrm{M}=$ macho, $\mathrm{F}=$ hembra, $\mathrm{n}=$ número de contenidos estomacales

\begin{tabular}{lccrc}
\hline Locality & Sex & $\mathrm{n}$ & $\begin{array}{c}\text { Range TL } \\
(\mathrm{cm})\end{array}$ & \multicolumn{1}{c}{$\begin{array}{c}\text { Mean } \pm \text { SD } \\
(\mathrm{cm})\end{array}$} \\
\hline Necochea $(\mathrm{n}=15)$ & $\mathrm{F}$ & 8 & $100-149.0$ & $123.4 \pm 19.3$ \\
& $\mathrm{M}$ & 7 & $103.5-141.5$ & $117.4 \pm 15.5$ \\
Claromecó $(\mathrm{n}=33)$ & $\mathrm{F}$ & 13 & $98-160.5$ & $128.0 \pm 18.4$ \\
& $\mathrm{M}$ & 20 & $87.4-142.0$ & $118.6 \pm 11.2$ \\
Monte Hermoso $(\mathrm{n}=7)$ & $\mathrm{F}$ & 2 & $144.5-150.0$ & $147.3 \pm 3.9$ \\
& $\mathrm{M}$ & 5 & $98.3-129.0$ & $115.2 \pm 11.8$ \\
Bahía Blanca $(\mathrm{n}=4)$ & $\mathrm{F}$ & 2 & $93.3-129.7$ & $111.5 \pm 25.7$ \\
& $\mathrm{M}$ & 2 & $127.5-135.0$ & $131.3 \pm 5.3$ \\
\hline
\end{tabular}

species in the study area is considerably lower compared with those studies along it distribution range. We identified 11 prey species in the diet of franciscana dolphins from southern Buenos Aires coast: seven teleost fish, two cephalopods and two crustaceans (Table 2). However, seven species of those 11 prey species found in the diet, appeared with a very low frequency of occurrence not exceeding in each case a $\% \mathrm{FO}=9$.

Teleosts were recorded in $\sim 93 \%$ of the 59 stomachs and corresponded to 1,329 individuals. The striped weakfish, Cynoscion guatucupa, was the most important teleost $(n=1,073 ; \% I R I=87.8)$, whereas the remaining fish species represented about $12 \%$ of IRI. For cephalopods, the main prey species was the squid Loligo sanpaulensis, with a $\% \mathrm{FO}=90$ (Table 2 ). The high number of cephalopod beaks found in stomachs $(n=3,660)$ in comparison with otoliths $(n=1,329)$ could reflect a differential rate of digestion rather than the importance in the diet; cephalopod beaks resist or are retained in the stomach longer than otoliths (Bowen 2002). Crustaceans, identified as Artemesia longinaris (marine shrimp) and Pleoticus muelleri (Argentine red shrimp), appeared in a low frequency of occurrence ( \% 16). However, given the relatively quick digestion of crustaceans, their low values do not necessarily mean a minor importance of this group (Bowen 2000). All this kind of bias could be accounted with other method such as the analysis of stable isotopes, which are really effective in trophic reconstruction when used together with stomach contents (Sheffield et al. 2001). 
Table 2. Diet composition of franciscana dolphins from southern Buenos Aires, Argentina / Composición de la dieta del delfín franciscana del sur de la provincia de Buenos Aires, Argentina

\begin{tabular}{llcccccc}
\hline Prey item & Common name & $\% \mathrm{FO}$ & $\mathrm{n}$ & $\% \mathrm{~N}$ & $\% \mathrm{~W}$ & IRI & $\% \mathrm{IRI}$ \\
\hline Teleosts & & 93 & 1329 & & & & \\
Cynoscion guatucupa & Striped weakfish & 73.7 & 1073 & 80.7 & 60.2 & 10383 & 87.8 \\
Trachurus lathami & Rough scad & 31.6 & 84 & 6.3 & 20 & 831.2 & 7 \\
Engraulis anchoita & Argentine anchovy & 31.6 & 69 & 5.2 & 12.6 & 562.1 & 4.7 \\
Micropogonias furnieri & White croacker & 5.3 & 53 & 4 & 1.3 & 28 & 0.2 \\
Porichthys porosissimus & Lantern midshipman & 1.7 & 15 & 1.1 & 4.8 & 10.3 & 0.1 \\
Raneya fluminensis & Curk-eels & 5.3 & 11 & 0.8 & 1.1 & 10.2 & 0.1 \\
Percophis brasiliensis & Brazilian flathead & 1.7 & 1 & 0.1 & & & \\
N.i & & & 23 & 1.7 & & & \\
Cephalopods & & 89.5 & 3660 & & & & \\
Loligo sanpaulensis & Long finned-squid & 89.5 & 3654 & 99.8 & 99.8 & 9140.7 & 99.9 \\
Octopus tehuelchus & Tehuelche octopus & 1.7 & 6 & 0.2 & 0.2 & 0.4 & 0.01 \\
Crustaceans & & 15.8 & 88 & & & & \\
Artemesia longinaris & Marine shrimp & 8.8 & 61 & 69.3 & 36.5 & 927.9 & 74.8 \\
Pleoticus muelleri & Argentine red shrimp & 3.5 & 24 & 27.3 & 61.9 & 312.9 & 25.2 \\
Penaeidae & & & 3 & & & & \\
\hline
\end{tabular}

N.i= number of unidentified otoliths

We estimated prey size from all prey species in the diet (Table 3). The sizes of main fish correspond to juveniles in C. guatucupa and Micropogonias furnieri, and to adults in Engraulis anchoita and Trachurus lathami (Cousseu \& Perrotta 2004). In other areas of distribution, preference for small sizes or juvenile fish was also observed (Ott 1995, Bassoi 2005, Cremer et al. 2012). On the other hand, franciscana does appear to select larger squids, because most cephalopods consumed in southern Buenos Aires were mature individuals $(67 \%=11-13 \mathrm{~cm}$ ML). This species concentrate in the area in highest abundances of mature animals for breeding purposes between October and December (Castellanos et al. 1968, Vigliano 1985). Correlation coefficients showed no association between dolphins TL and prey TL $(C$. guatucupa and L. sanpaulensis) $(r=0.1, P>0.05$ and $r=$ $0.06, P>0.05$, respectively).
We did not find significant differences in mean size of C. guatucupa or $L$. sanpaulensis between male and female dolphins ( $\mathrm{U}=0.43, P>0.05 ; \mathrm{U}=1.66, P>0.05$, respectively). However, mean size of $C$. guatucupa consumed by franciscana differed significantly between geographical areas $(\mathrm{H}=14.17, P=0.003)$. C. guatucupa consumed near Bahía Blanca estuary and Monte Hermoso (Mean $\pm \mathrm{SD}=$ $6.6 \pm 1.6 \mathrm{~cm})$ were significantly smaller than those consumed in Necochea $(13.8 \pm 1.1 \mathrm{~cm})(P=0.007, P=0.029$, respectively). Bahía Blanca estuary and surrounding waters are an important nursery ground for C. guatucupa, where juveniles remain during their first year of life (TL less than $20 \mathrm{~cm}$ ) (López-Cazorla 2000). Fish aged between The fact that fish aged between 2 and 4 years were not found in the estuary (López Cazorla 2000), maybe explain the significant small size of fish consumed in the estuary of Bahia Blanca and Monte Hermoso. Also, we did not find significant differences in the mean size of $L$. sanpaulensis between areas $(\mathrm{H}=3.04, P>0.05)$. 
Table 3. Prey size (TL) of franciscana dolphin from southern Buenos Aires, Argentina. Range, mean \pm SD and commercial size (cm) (Cousseau \& Perrota 2000) / Talla de las presas (LT) del delfín franciscana del sur de la provincia de Buenos Aires, Argentina. Rango, media \pm DS y talla comercial $(\mathrm{cm})$ (Cousseau \& Perrota 2000)

\begin{tabular}{lcccc}
\hline Prey item & $\mathrm{n}$ & Range TL & $\begin{array}{c}\text { Mean TL or } \\
\text { ML } \pm \text { SD }\end{array}$ & $\begin{array}{c}\text { Commercial } \\
\text { size }\end{array}$ \\
\hline Teleosts & & & & \\
$\quad$ Cynoscion guatucupa & 295 & $2.8-28.1$ & $8.7 \pm 5.1$ & $35-45$ \\
$\quad$ Trachurus lathami & 56 & $7.6-21.5$ & $14.1 \pm 3.2$ & $8-23$ \\
$\quad$ Engraulis anchoita & 50 & $8.8-17.3$ & $14.2 \pm 2.4$ & $14-19$ \\
$\quad \begin{array}{l}\text { Raneya fluminensis } \\
\quad \text { Micropogonias furnieri }\end{array}$ & 11 & $10.3-16.4$ & $13.3 \pm 2.3$ & No commercial \\
Cephalopods & 50 & $4.1-7.8$ & $6.1 \pm 0.9$ & $30-50$ \\
$\quad$ Loligo sanpaulensis & 1402 & $4.7-17.9$ & $11.7 \pm 1.8$ & $<15$ \\
Crustaceans & & & & $6-13.5$ \\
$\quad$ Artemesia longinaris & 5 & $4.6-11.8$ & $7.2 \pm 2.8$ & \\
$\quad$ Pleoticus muelleri & 2 & $9.4-10.6$ & $10 \pm 0.9$ & \\
\hline
\end{tabular}

$\mathrm{n}=$ Number of specimens measured. Total length (TL) was estimated for fish and crustaceans and mantle length (ML) for cephalopods

The number and composition of prey species varied along the distribution of franciscana dolphin (Ott et al. 1995, Di Beneditto \& Ramos 2001, Rodriguez et al. 2002, Bassoi 2005, Cremer et al. 2012) and could be related to changes in prey availability and accessibility (Danilevicz et al. 2002). In the study area, the main prey of this dolphin are the most abundant species (Milessi 2008), characterizing an opportunistic behavior (Begon et al. 1996), also observed in other areas of the distribution of this species (Ott et al. 1995, Bassoi 2005, Cremer et al. 2012). Seasonal fluctuations in the franciscana's diet components coincide with the pattern variation observed in the abundance of the prey species off southern Brazil in different seasons of the year, indicating that the species may feed opportunistically upon those preys most frequent in the area (Bassoi 2005). Another evidence of predation on abundant prey was presented by Bassoi \& Secchi (1999) with the reduction on occurrence of Micropogonias furnieri and Macrodon ancylodon in the diet of franciscana from southern Brazil, through a period of 15 years, as a consequence of stock depletion for those species (Haimovici 1998). Then, an opportunistic behavior could lead the species to change its foraging patterns as a consequence of fish stock reduction (Danilevicz et al. 2002).

Most of prey species present in the diet of franciscana from southern Buenos Aires province are of commercial interest (Table 3). The squid L. sanpaulensis, a main prey in the diet of franciscana dolphin, is an important resource for the small scale coastal fisheries developed along most of its distribution, from southern Brazil to the San Jorge Gulf in Argentina (Vigliano 1985, Ré \& Beron 1999, Barón \& Ré 2002), although it represented only a small percentage of the total squids landings of Argentina (FAO 2005). The same occurs with the red shrimp, Pleoticus muelleri, which represents one of the most important fisheries in the country because of its high commercial value (Bertuche et al. 2000, FAO 2005, De la Garza et al. 2009).

Cynoscion guatucupa, the main fish in the diet, together with Micropogonias furnieri are the most important fishing coastal resources of Argentina and Uruguay (Ruarte \& Aubone 2008). In Bahía Blanca estuary, 
C. guatucupa supports important commercial fisheries although historical data show dramatic variability in its population over the last 10 years, probably due to the fishing pressure exerted on this species (Lopez-Cazorla 2000). Although a significant decrease was observed in C. guatucupa biomass between the periods 1981-1983 and 2004-2005, this species is still being abundant in the Buenos Aires coastal system (FAO 2005, Milessi 2008). Commercial sizes of $C$. guatucupa range between 35 and $45 \mathrm{~cm}$ of TL (Cousseu \& Perrotta 2004), but the estimated mean size of this species consumed by franciscana was $\sim 9 \mathrm{~cm}$, reaching a maximum size of $28 \mathrm{~cm}$. Although fisheries target larger individuals of $C$. guatucupa than those consumed by the franciscana, the use of different sizes does not necessarily imply less intensity of the interaction (Szteren et al. 2004). Consequently, there might be an overlap between franciscana and fisheries in the use of C. guatucupa as a resource. The others prey species, Engraulis anchoita, Trachurus lathami, Loligo sanpaulensis and Artemesia longinaris show sizes which overlaps with those of fisheries (Cosseau \& Perrota 2004).

Franciscana dolphin has been classified as 'vulnerable' in its whole distribution, principally as a consequence of the incidental mortality in artisanal fisheries. In consequence, the detection of trophic overlapping with fisheries is important as a first step for marine mammal conservation in a dynamic ecosystem where fishery activity is growing continually and where the overlapping of target species and prey that are subject to overfishing could enhance the vulnerability of franciscana in southern Buenos Aires, Argentina.

\section{ACKNOWLEDGMenTs}

We are extremely grateful to the unconditional help and collaboration of the artisanal fishing communities of Southern Buenos Aires province. We wish to thank people who collaborated with the field work: V. Panebianco, A. Suarez, F. Pérez, M. Bobinac, D. del Castillo, S. Ceballos, M. Negri, V. Di Martino, M. Dassis, G. Giardino, A. Mandiola, M. Sotelo, V. Massola, A. Areco, K. Arias and L. Nogueira. In addition, we are grateful to A. Volpedo for her help in otolith identification. Thanks are also due to N. A. Dellabianca who read an earlier version of the manuscript and M. Liljesthrom for his help with the English language. MNPV was supported by a Postdoctoral grant from the Consejo Nacional de Investigaciones Científicas y Técnicas (CONICET) of Argentina. Financial support was given by Cetacean Society International (CSI), Society of Marine Mammalogy (SMM) and Fundación de Historia Natural Félix de Azara (FHN). Thanks are also given to Bill Rossiter, their continual and encouraging help and support with this project.

\section{LITERATURE CITED}

Barón PJ \& ME Ré. 2002. Reproductive cycle and population structure of Loligo sanpaulensis of the northeastern coast of Patagonia. Bulletin of Marine Science 71: 175-186.

Bassoi M. 2005. Feeding ecology of franciscana dolphin, Pontoporia blainvillei (Cetacea: Pontoporiidae), and oceanographic processes on the Southern Brazilian coast. PhD Thesis, School of Ocean \& Earth Sciences, University of Southampton, Southampton, 190 pp.

Bassoi M \& ER Secchi. 1999. Temporal variation in the diet of franciscana, Pontoporia blainvillei (Cetacea, Pontoporiidae), as a consequence of fish stocks depletion off southern Brazil. Technical Paper WP9, IV Workshop para a Coordenação da Pesquisa e Conservação da Franciscana, Pontoporia blainvillei, no Atlântico Sul Ocidental. 05-09 November, Porto Alegre. 5 pp.

Begon M, J Harper \& CR Townsend. 1996. Ecology: Individuals, populations and communities, $738 \mathrm{pp}$, Blackwell, Oxford.

Bertuche D, C Fischbach, A Roux, M Fernández \& R Piñero. 2000. Langostino (Pleoticus muelleri). In: Bezzi S, R Akselman \& E Boschi (eds). Síntesis del estado de las pesquerías marítimas argentinas y de la Cuenca del Plata. Años 1997-1998, con una actualización de 1999. Publicaciones Especiales, Instituto Nacional de Investigación y Desarrollo Pesquero (INIDEP), Mar del Plata, pp. 179-190.

Beverton RJH. 1985. Analysis of marine mammal-fisheries interactions. In: Beddington JR, RJH Beverton \& DM Lavigne (eds). Marine mammals and fisheries, pp. 3-33. George Allen \& Unwin, London.

Bordino P \& D Albareda. 2004. Incidental mortality of Franciscana dolphin Pontoporia blainvillei in coastal gillnet fisheries in northern Buenos Aires, Argentina. International Whaling Commission Meeting, Sorrento, SC/56/SM11, 4 pp.

Bowen WD. 2000. Reconstruction of pinniped diets: accounting for complete digestion of otoliths and cephalopod peaks. Canadian Journal of Fisheries and Aquatic Sciences 75: 898905.

Brownell RL Jr. 1989. Franciscana, Pontoporia blainvillei (Gervais and d.Orbigny 1844). In: Ridgway SH \& RJ Harrison (eds). Handbook of marine mammals 4: 45-67. Academic Press, London.

Cappozzo HL, MF Negri, FH Pérez, D Albareda, F Monzón \& JF Corcuera. 2007. Incidental mortality of Franciscana Dolphin, (Pontoporia blainvillei) in Argentina. Latin American Journal of Aquatic Mammals 6(2): 127-137. 
Casey J \& R Myers. 1998. Near extinction of a large, widely distributed fish. Science 281: 690-692.

Castellanos ZA, M Morris, AM Corgnati \& AM Cela. 1968. State population of Loligo brasiliensis in January 1967. Notas, Comisión Investigaciones Científicas de Buenos Aires 5(9): 1-13.

Castley JG, VG Cockcroft \& GI Kerley. 1991. A note on the stomach contents of fur seals Arctocephalus pusillus pusillus beached on the South- East coast of South Africa. African Journal of Marine Science 2: 573-577.

Corcuera J. 1994. Incidental mortality of Franciscana in Argentine Waters: The threat of small fishing camps. Report of the International Whaling Commission, Special Issue 15: 291-294.

Cortés E. 1997. A critical review of methods of studying fish feeding based on analysis of stomach contents: application to elasmobranch fish. Canadian Journal of Fisheries and Aquatic Sciences 54: 726-738.

Cousseau MB \& RG Perrota. 2000. Peces marinos de Argentina. Biología, distribución, pesca, 167 pp. Instituto Nacional de Investigación y Desarrollo Pesquero (INIDEP), Mar del Plata.

Cremer MJ, PC Pinheiro \& PC Simões-Lopes. 2012. Prey consumed by Guiana dolphin Sotalia guianensis (Cetacea, Delphinidae) and franciscana dolphin Pontoporia blainvillei (Cetacea, Pontoporiidae) in an estuarine environment in southern Brazil. Iheringia, Série Zoologia 102(2): 131-137.

Crespo EA, G Harris \& R González. 1998. Group size and distributional range of the Franciscana Pontoporia blainvillei. Marine Mammal Science 14(4): 845-849.

Danilewicz D, F Rosas, R Bastida, J Marigo, M Muellbert, D Rodriguez, J Lailson-Brito Jr, V Ruoppolo, R Ramos, M Bassoi, PH Ott, G Caon, AM Rocha, JL Catao-Dias \& ER Secchi. 2002. Report of the Working Group on Biology and Ecology. Latin American Journal of Aquatic Mammals 1: 25-42.

De la Garza J. 2003. Relaciones morfométricas del langostino patagónico, Pleoticus muelleri. Informe Técnico INIDEP, Mar del Plata 101: 1-9.

De la Garza J \& C Fischbach. 2009. Obtención de índices de mortalidad y tasas de explotación del langostino (Pleoticus muelleri) en las temporadas de pesca 1992-2008 a partir de datos de producción y desembarque. Informe Técnico INIDEP, Mar del Plata 63: 1-16.

Di Beneditto APM \& RMA Ramos. 2001. Biology and conservation of the franciscana (Pontoporia blainvillei) in the north of Rio de Janeiro State, Brazil. Journal of Cetacean Research Management 3(2): 185-192.

Di Beneditto APM, MVB Santos \& MV Vidal Jr. 2009. Comparison between the diet of two dolphins from southeastern Brazil: proximate-composition and caloric value of prey species. Journal of the Marine Biological Association of the United Kingdom 89: 903-905.
Di Rienzo JA, F Casanoves, MG Balzarini, L Gonzalez, M Tablada \& CW Robledo. 2011. InfoStat software estadístico. Universidad Nacional de Córdoba, Córdoba. <http://www.infostat.com.ar>

Donovan GP \& A Bjørge. 1995. Dall's porpoise, Phocoenoides dalli - Introductory remarks. In Bjørge A \& GP Donovan (eds). Biology of the Phocoenids. Report of the International Whaling Commission, Special Issue 16: 378-380.

FAO. 2005. Resumen informativo sobre la pesca por países. La República Argentina. FAO Resumen Informativo sobre la Pesca por Paises, FID/CP/ARG. <http://www.fao.org/fi/ oldsite/FCP/es/ARG/profile.htm>

Fitch JE \& RL Brownell Jr. 1971. Food habits of the franciscana, Pontoporia blainvillei (Cetacea, Platanistidae) from South America. Bulletin of Marine Science 21: 626636.

Gervais P \& A D'Orbigny. 1844. Mammalogie. Bulletin de la Société Philomathique, Paris, April 27, 1844: 38-40.

Haimovici M. 1998. Present state and perspectives for the southern Brazil shelf demersal fisheries. Fisheries Management and Ecology 5: 277-289.

Jensen OP, TA Branch \& R Hilborn. 2012. Marine fisheries as ecological experiments. Theoretical Ecology 5: 3-22.

López-Cazorla A. 2000. Age structure of the population of weakfish Cynoscion guatucupa in the Bahía Blanca waters, Argentina. Fisheries Research 46: 279-286.

Milessi A. 2008. Modelación ecotrófica en el ecosistema costero Argentino-Uruguayo $\left(34^{\circ}-41^{\circ} \mathrm{S}\right)$ años 2004-05. Informe Técnico INIDEP, Mar del Plata 6: 1-25.

Morissette L, V Christensen \& D Pauly. 2012. Marine Mammal Impacts in Exploited Ecosystems: Would Large Scale Culling Benefit Fisheries? PloS ONE 7(9): e43966. <doi:10.1371/journal.pone.0043966>

Negri MF, P Denuncio, MV Panebianco \& HL Cappozzo. 2012. Bycatch of franciscana dolphins Pontoporia blainvillei and the dynamic of artisanal fisheries in the species' southernmost area of distribution. Brazilian Journal of Oceanography 60(2): 151-160.

Norris KS. 1961. Standardized methods for measuring and recording data on the smaller cetaceans. Journal of Mammalogy 42: 471-476.

Northridge SP. 1984. World review of interactions between marine mammals and fisheries. FAO Fisheries Technical Paper 251: 1-194.

Ott PH. 1995. Estudo da ecologia alimentar de Pontoporia blainvillei (Gervais \& D.Orbigny, 1844) (Cetacea, Pontoporiidae) no litoral norte do Rio Grande do Sul, sul do Brasil. Bachelor Dissertation, Universidades Federal do Rio Grande do Sul, Porto Alegre, 69 pp.

Pauly D \& ML Palomares. 2005. Fishing down marine food web: it is far more pervasive than we thought. Bulletin of Marine Science 76(2): 197-211. 
Pauly D, AW Trites, E Capuli \& V Christensen. 1998. Diet composition and trophic levels of marine mammals. ICES Journal of Marine Science 55: 467-481.

Pauly D, V Christensen, S Guenette, TJ Pitcher, UR Sumaila, CJ Walters, R Watson \& D Zeller. 2002. Towards sustainability in word fisheries. Nature 418: 689695.

Pineda SE, A Aubone \& NE Brunetti. 1996. Identificación y morfometría comparada de las mandíbulas de Loligo gahi y Loligo sanpaulensis (Cephalopoda, Loliginidae) del Atlántico Sudoccidental. Revista de Investigación Desarrollo Pesquero (INIDEP) 10: 85-99.

Pinedo MC. 1982. Análises dos conteúdos estomacais de Pontoporia blainvillei (Gervais \& d'Orbigny, 1844) e Tursiops gephyreus (Lahille, 1908) (Cetacea, Platanistidae e Delfinidae) na zona estuarial e costeira do Rio Grande, RS, Brasil. MSc Thesis, Fundação Universidade do Rio Grande, Rio Grande, 95 pp.

Pinkas LM, S Oliphant \& ILK Iverson. 1971. Food habits of albacore, bluefin tuna and bonito in Californian waters. California Fish and Game 152: 1-105.

Praderi R, MC Pinedo \& EA Crespo. 1989. Conservation and management of Pontoporia blainvillei in Uruguay, Brazil and Argentina. In: Perrin WF, RL Brownell Jr, Z Kaiya \& L Jiankang (eds). Biology and conservation of the River Dolphins. Occasional Papers of the IUCN Species Survival Commission 3: 52-56.

Ré ME \& JC Berón. 1999. Relevamiento de la pesca artesanal con red de costa en la Provincia del Chubut, patagonia argentina. Naturalia Patagónica 2: 1-69.

Reeves RR, BD Smith, E Crespo, G Notarbartolo di Sciara \& the Cetacean Specialist Group. 2003. Dolphins, whales, and porpoises: 2003-2010 conservation action plan for the world's cetaceans, 139 pp. IUCN Species Survival Commission, Gland.

Reeves RR, ML Dalebout, TA Jefferson, L Karczmarski, K Laidre, GO'Corry-Crowe, L Rojas-Bracho, ER Secchi, E Slooten, BD Smith, JY Wang, AN Zerbini \& K Zhou. 2008. Pontoporia blainvillei. In: IUCN 2012. IUCN Red List of Threatened Species. Version 2012.1. <www.iucnredlist.org>.
Rodríguez D, L Rivero \& R Bastida. 2002. Feeding ecology of franciscana in marine and estuarine waters of Argentina. Latin American Journal of Aquatic Mammals 1 (Special Issue 1): 77-94.

Ruarte C \& A Aubone. 2008. Compendio de las evaluaciones de pescadilla de red en el período 2001-2007. Recomendaciones de manejo para el año 2008. Informe Técnico INIDEP, Mar del Plata 30: 1-11.

Secchi ER. 2010. Life history and ecology of Franciscana, Pontoporia blainvillei (Cetacea, Pontoporiidae). In: RuizGarcia M \& JM Shostell (eds). Biology, evolution and conservation of river dolphins within South America and Asia. Wildlife Protection, Destruction and Extinction Series, pp. 323-339. Nova Science Publishers, Hauppange.

Secchi ER, AN Zerbini, M Bassoi, L Dalla Rosa, LM Möller \& CC Rocha-Campos. 1997. Mortality of franciscanas, Pontoporia blainvillei, in coastal gillneting in southern Brazil: 1994-1995. Reports of the International Whaling Commission 47: 653-658.

Secchi ER, D Danilewicz \& PH Ott. 2003. Applying the phylogeographic concept to identify franciscana dolphin stocks: implications to meet management objectives. Journal Cetacean Research Management 5: 61-68.

Sheffield G, FH Fay, H Feder \& BP Kelly. 2001. Laboratory digestion of prey and interpretation of walrus stomach contents. Marine Mammal Science 17: 310-330.

Siciliano S. 1994. Review of small cetaceans and fishery interactions in coastal waters of Brazil. Reports of the International Whaling Commission 15: 241-250.

Szteren D, DE Naya \& M Arim. 2004. Overlap between pinniped summer diet and artisanal fishery catches in Uruguay. The Latin American Journal of Aquatic Mammals 3(2): 119-125.

Vigliano PH. 1985. Contribución al conocimiento de Loligo brasiliensis (Blainville, 1823) (Mollusca, Cephalopoda) en aguas argentinas. PhD Thesis, Universidad Nacional de $\mathrm{La}$ Plata, La Plata, 183 pp.

Volpedo AV \& DD Echeverría. 2000. Catálogo y clave de otolitos para la identificación de peces del Mar Argentino, 90 pp. Editorial Dunken, Buenos Aires. 